\title{
ASSESSMENT OF CAPABILITIES AND INADEQUACIES OF EVIDENCE IN RAPE UNDER ISLAMIC LAW
}

\author{
Hajar Azari*
}

There are two important points that this paper will clarify in detail. Firstly, the procedure for proving rape in Islamic law, which is interpreted in a certain way in some Islamic states, does not seem to be efficient and protective for victims. First of all, finding witnesses who have seen the act of rape and who would accept to come to the court for testimony is difficult. In addition, based on Islamic ruling, the testimony of fewer than four people for proving the act of Zina (including rape) would expose the witnesses to receiving the punishment of slander which is discouraging for the witnesses. ' Secondly, different schools of law disagree in terms of what evidence should be provided and which procedure(s) to be followed, i.e. some schools accept knowledge (or conviction) of judges ${ }^{2}$ or circumstantial evidence as well. The disagreement amongst Islamic schools is rooted in the differences observed in the Islamic schools' interpretations of the nature of the right violated in case that rape occurs. Islamic schools have various opinions in determining the rights which are violated by rape. Because of different interpretation, some schools offer to accept circumstantial evidence or knowledge of judges beside traditional evidence. Although these possibilities in the Islamic system seem very promising for victims, they do not apply these powers properly in criminal procedures. Because the judges who consider rape as Zina prefer to only consider traditional evidence such as testimony and confession that unfortunately, result in several problems for the victims.

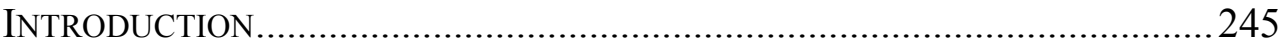

A. The Category of Crimes in Islamic Criminal Law .................. 247

B. Different Types of Rights and Crimes under Islamic Criminal Law

I. (IN)EFFICIENCY OF TRADITIONAL ISLAMIC EVIDENTIARY SYSTEM OF RAPE

A. Confession

\footnotetext{
* Post-doctoral Researcher, Law and Development Research Group, Faculty of law, University of Antwerp, Belgium. I offer my sincere appreciation to my supervisor Professor. Koen De Feyter for his help and support during my research. The author researched on "protection of women victim of rape; Islamic and international legal perspectives". Research field: Victomology, Women' Rights, Islamic Law and International Criminal Law.

${ }^{1}$ JONATHAN BROWN, RAPE IN ISLAMIC LAW, IN THE OXFORD ENCYCLOPEDIA OF ISLAM AND LAW 5 (New York, Oxford University Press, Forthcoming).

${ }^{2}$ Knowledge of judges means Conviction of judges that can be provided by any form of evidence including circumstantial evidence and convinces judges whether or not that specific crime accrued.
} 
B. Testimony.... 252

II. DIFFERENT ISLAMIC SCHOOLS AND THE EVIDENTIARY SYSTEM OF RAPE

254

A. Different Views Concerning the Validity of Knowledge of Judge.. 255

B. The Role of Knowledge of Judges in Criminal Procedure ....... 258 III. NEW APPROACH TO EVIDENTIARY SYSTEM ..........................................260

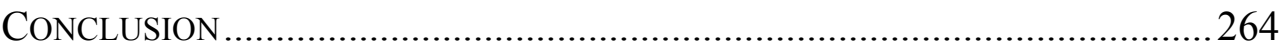

\section{INTRODUCTION}

When the legal controversy reaches the court, both parties (including victims or the accused) seek to provide some evidence in order to uphold his or her own rights. Evidence could be defined in criminal affairs as any legal data and information, which proves the existence or non-existence of a fact and/or credibility of a claim. In every case, the judge considers the evidence gathered before pronouncing the sentence. He can look for other evidence when deemed necessary. ${ }^{3}$ There is a law that governs these forms of evidence and covers different types of evidence, such as testimony, exhibit, or other documentary materials. Today, forms of evidence to prove crimes are different from the past. Evidence can include a huge variety of elements from testimony to scientific evidence that help both parties to defend their rights. Giving evidence in rape cases is much more difficult than in other cases. Because of the nature of this crime, providing evidence in court can even be a particularly traumatic experience for the victims. ${ }^{4}$ Some victims may find it difficult to give evidence of witness in front of the defendant fearing for their own safety, a desire of revenge from the accused, violation of their privacy etc.

The current treatment of rape in the penal codes of Islamic states has been increasingly assessed over the last two decades. Many cases in which women claimed to have been sexually assaulted and raped have been highlighted in which women could not provide enough evidence to prove non-consent. Consequently, in some cases, victims have been punished for Zina ${ }^{5}$

\footnotetext{
${ }^{3}$ Mohammad Ashouri, Code of Criminal Procedure 59 (1, Samt publication 2002).

${ }^{4}$ Liz Kelly and Great Britain, Routes to (in) Justice: A Research Review on the Reporting, InVestigation and Prosecution of Rape Cases (Her Majesty's Crown Prosecution Service Inspectorate 2001). CPS Policy for Prosecuting Cases of Rape, available at http://www.cps.gov.uk/publications/prosecution/rape.html\#_07. JESSICA HARRIS, SHARON GRACE AND Great Britain, A Question of EVIDENCE?: InVESTIGATING AND ProseCuting RAPE IN THE 1990s (Home Office London 1999).

${ }^{5}$ Zina means having extramarital sexual relationship, which is forbidden under Islamic law.
} 
(fornication). ${ }^{6}$

With regard to Islamic law, a special way of legal evidence is used to prove some crimes (mainly Hudud) such as Zina. This system has a traditional-jurisprudential basis and is not easy to violate and change. In other words, in Islamic law, providing the special form of evidence to prove crimes is not a requirement except for specific cases in which the Islamic law has explicitly announced the necessity to offer another form of evidence. They are mainly in the category of Hudud crime i.e. Zina. ${ }^{7}$ Regardless of different methods and different possible ways that can be offered to victims to give evidence to courts, the situation of rape victims who live in Islamic states is more difficult since Islamic law has not determined specific types of evidence different from those applicable for Zina. Thus, evidence of rape is linked to evidence of Zina, which is very difficult for victims to provide.

As legalizing appropriate and efficient evidence can have an influential role in guaranteeing the rights of victims, the existing evidence used for proving rape will be critically reviewed in relation to different Islamic schools, with an evaluation of its capabilities and strengths in the protection of victims. This will be followed by an evaluation of whether or not they are useful and helpful for these victims and whether the influences come from the Islamic law itself or it is because of certain interpretation of some Islamic states of Islamic law. ${ }^{8}$

\footnotetext{
${ }^{6}$ Azman Mohd Noor, A Victim's Claim of Being Raped Is Neither a Confession to Zina Nor Committing Qadhf (Making False Accusation of Zina), 8 Muslim World Journal of Human Rights 1 (2011). ${ }_{7}$ Akhundi Mohammad, Proving Sexual Crimes in Another Review, The Magazine OF THE BooK OF WOMEN, Winter 2004, at 22. This evidentiary system in Zina etc. is helpful because innocent people accused of those crimes could be exculpated in the court and their deeds could never be disclosed. ${ }^{8}$ J. Brown, M. Horvath, L. Kelly and N. Westmarland, Connections and Disconnections: Assessing Evidence, Knowledge and Practice in Responses to Rape, 2010, Policy for Prosecuting Cases of Rape CPS (March 2009), Helping victims and witnesses to give evidence is also very important discussion in this regard: there are different ways for victims of rape to give evidence before the court. For example, in the case that victims are afraid of their safety or privacy etc, it would be possible for the courts to admit evidence through particular measures such as recording the statements of the victims and playing them in the court. This means that the victim or witness will not have to give "live" evidence about what happened to them, but they will still have to answer questions presented by the defendant's lawyer in cross-examination. It is also possible to give evidence from behind a screen in a courtroom to prevent the victims (or other witness) and the defendant from seeing each other; and it is possible to give evidence through a live television link to prevent victims from going to the courts. It seems that it is up to the court to decide whether to grant or refuse applications for these special measures in these cases. These measures can be taken in both early and even last stages of the investigation. The use of an intermediary is a kind of particular measure that is available for vulnerable victims. This measure will enable victims to communicate with courts. The intermediaries have to be approved by the courts and the work with victims and witness to make sure that they understand correctly the questions presented in the court. They can also assist victims to provide evidence, so that the victims will be able to give their best evidence to the courts. Taking this measure is also crucial for the deaf victims or the victims who have language problems.
} 
It should be mentioned that although Islamic schools of thought have differences, there are many commonalities amongst them as well. Since this part will include both Sunni and Shiite, everything that is common amongst them will be explained altogether. Then where there are differences, distinctions will be highlighted. Therefore, no reference to a particular school should be interpreted as a common point amongst all. In addition, when it comes to practice of Islamic states, it focuses more on Iranian law, which is an interpreted version of Shiite jurisprudence.

Before embarking on the core of this research, it is important to explain some Islamic key terms, namely the category of crimes in Islamic legal systems and the nature of rights and crimes under the Islamic law.

\section{A. The Category of Crimes in Islamic Criminal Law}

Under Islamic law, crimes fall into four categories: Hudud (Legal Punishments), Qisas (Retaliation), Diyat (s. Diyah) (Blood-Money) and Tazir (Discretionary Punishments). ${ }^{9}$ This classification is based on two sources of the Islamic law, namely the Quran and Traditions of the Prophet (Sunna).

\section{Hudud (Singular: Had)}

Hudud meaning, "limits"10 is the most important category that includes the crimes specified in the Quran. Legally, it refers to the types of penalties divinely prescribed by God in the Qur'an and Sunna. Such crimes include theft, adultery, fornication, alcohol use, rebellion, and apostasy that are considered crimes against God and society, however, there has been disagreement among the jurists of different schools of Islamic law over what constitutes a Had. ${ }^{11}$ The criterion of a Had is that the rights of God take precedence, which will be explained in the next section.

\section{Qisas and Diyah}

These categories include the crimes committed against people, such as murder and battery. The punishments for these kinds of crimes are

\footnotetext{
${ }^{9}$ For more information please see M. Cherif Bassiouni, The Islamic CRIMINAL JustiCE System (Oceana Publications New York 1982); Mohamed S. El-Awa, Punishment IN Islamic LaW (American Trust Pub. 1981); Matthew Lippman, SeAn Mcconville and Mordechai Yerushalmi, IsLAMic CRiminal LAw AND Procedure: An InTRODUCtion (Praeger New York 1988).

${ }^{10}$ Ibn Manzur, Lisdn al-'arab, 4 BEIRUT: DAR SADIR, ND 93 (1990).

${ }^{11}$ For more information please see DOI, A.R.I. AND A. ClARKE, SHARIAH: ISLAMIC LAW 221-228 (TaHa Publishers 2008).
} 
retaliation (Qisas) or financial compensation (Diyah or blood money). The heirs of the victim exclusively hold the right of Qisas. Legally, Qisas means the law of equality or equitable reprisal for a murder. ${ }^{12}$ The heir of a victim has the following options: He or she may ask for retaliation, seek monetary compensation or demand an apology. ${ }^{13}$ This approach is a mixture of "restorative justice" and "retributive justice". Therefore, Diyah is compensation paid to victims or their family. One who seeks compensation cannot demand retribution.

\section{Tazir}

This category includes any crime that does not fit into Hudud or Qisas and has no specific punishment in the Quran. These types of crimes range from homosexuality to perjury through treason. The punishments in this category can be determined by legislative system(s) or by judges. These acts mainly endanger public order or state security. An important function of Tazir is to provide grounds for the punishment of those who have committed crimes which are somewhat similar to Hudud crimes, or crimes against people, but which cannot be sentenced to the appropriate punishment because of procedural reasons. For example, Tazir punishments are applied for acts that do not have adequate requirements of Hudud or Qisas such as theft of an item that is not of sufficient value to qualify for a Hudud offence. This is also the case for acts that are logically punishable by Hudud, but due to insufficient or doubtful evidence, should be punished by Tazir.

"Tazir" is the most flexible category of Islamic law that can determine punishment according to Islamic principles and compatibility with social, cultural and legal developments. The most important differences between these categories are related to this issue of the extent to which they are a violation of rights of individuals, God or society. For example, in the Hudud category, God's rights are given more importance while in the Tazir category the rights of society for having public order or individual rights are considered as more important. However, sometimes Tazir can be imposed for the infringement of the rights of God and those of the individual as edification and a deterrent. ${ }^{14}$ The flexibility in Tazir distinguishes it from Had and Qisas and gives enough authority to judges or rules to determine and impose the appropriate penalty for crimes in line with the spirit of the

\footnotetext{
${ }^{12} \mathrm{Ibid}$, at 232.

${ }^{13}$ Mohamed S. El-Awa, Punishment in Islamic Law 74 (American Trust Pub. 1981).

${ }^{14}$ Ala'al-Dine Al-Kasani, Bada'al-sana'i, 7 DAR AL-KITAB AL-'ARABI 325 (Beirut 1982).
} 
Sharia. ${ }^{15}$ The evidentiary system applied to Tazir differs from Had penalties, therefore, crimes liable to a Tazir can be proved with a wide range of credible evidence, whereas crimes liable to a Had penalty are mainly proved through witnesses or the confession, more details will be provided in the next section. ${ }^{16}$

\section{B. Different Types of Rights and Crimes under Islamic Criminal Law}

Before discussing the definition of rape and its punishment, it is worth looking at different types of rights in Islamic law. This classification will help to fully understand the expressions and terms used in the following section. In Islamic jurisprudence, rights are divided into two known types: the rights of God and the rights of people. Different suggestions have been offered in defining each of these types. Concerning criminal law, violating the rights of God deserves some particular punishments because it is mainly synonymous with disobeying spiritual orders and sometimes performing sinful acts. For instance, Hudud crimes such as Zina are classified in this category. ${ }^{17}$ Therefore, forgiveness of the complainant (if there is any) does not have any influence on removing criminal or civil responsibility. The penalty in Hudud is unchangeable, they cannot be reduced or increased, so there is not a range of penalties from which to choose. Finally, there is no possibility of a pardon or intercession. ${ }^{18}$

Violating the rights of people includes crimes by which the rights of people are violated and involves damaging them, for instance, the issuance of a bounced cheque, barratry and abusiveness. ${ }^{19}$

There are different consequences that followed this division some of which have been discussed by Muslim Jurists. An example of this is the book entitled Fiqh al-Qadha written by Ardebili (who is a Shiite jurist) in which 14 effects related to this separation have been outlined. The most important ones have been mentioned here: ${ }^{20}$

1. The right of God is subject to the reduction and commutation of

\footnotetext{
${ }^{15}$ Abu-Muhammad Abd-Allah Ibn-Qudamah, Al-mughni, 7 DAR AL-KITAB AL-ARABI 801-802 (Beyrouth 1983). Muhammad Amin Ibn-Abidin, 6 Hashiyah radd al-muhtar 589-592 (1979).

${ }^{16}$ Abd Al-Qadir Awda, Al-tashri'al-jina'i al-Islami, 2 DAR AL-KATIB AL-'ARABI 294 (1980).

${ }^{17}$ Mohammad Hasan Marashi, New Attitudes in Criminal Laws of Islam, 1 MizAN PUBLICATION 237 (1994).

${ }^{18}$ Ibn Al-Humam, Sharh fat'h al-qadir, 3 AL-MAKTABAH AL-TIJARIYYAH AL-KUBRA 112-113 (CAIRO 1937).

${ }^{19}$ Rudolph Peters, Crime and Punishment in Islamic Law: Theory and Practice from the SixteEnth to the Twenty-First Century 7 (Cambridge University Press 2005).

${ }^{20}$ Abdu Alkarim Mousavi Ardebili, Fighh alghada the institution of Alnashr lejameah almufid, A.H., Altabah alsaniah (2003).
} 
sentence in contrast to the right of people.

2. The issuance of sentence in absentia is lawful in case of violation of people's rights in contrast to a violation of the rights of God.

3. As to a violation of rights of people, the issuance of a sentence and its execution is based on the claim of a complainant (or sometimes prosecutor) in contrast to the violation of rights of God.

4. The judge has the right of amnesty in some cases in case that the rights of God are violated, in contrast to a violation of the rights of people.

One of the important consequences of this categorization is the extent to which the judicial system is serious in the discovery, investigation and prosecution of the crime. With regard to crimes related to the violation of rights of God, which are devoid of any rights of people, (such as intimacy, adultery, or having consensual sexual relationship outside of marriage) state officials, judges etc. are not obliged to report and prove crime. Even the numerous Ahadith and different legal codes, some of which will be referred to in the following parts, show unwillingness of judges and legislators in the disclosure and prosecution of these crimes. On the other hand, regarding the crimes that violate the rights of people, the judicial system requires protecting the rights of individuals and does its best to find the truth. ${ }^{21}$

\section{I. (IN)EFFICIENCY OF TRADITIONAL ISLAMIC EVIDENTIARY SySTEM OF RAPE}

Based on traditional Islamic jurisprudence, rape is seen as a subdivision of fornication (Zina) in which the element of force and coercion is added. Consequently, all the issues of rape such as definition, punishment, proving through evidence are discussed under the category of Zina. ${ }^{22}$ To establish rape as a kind of Zina in which Hadd punishment (as violation of the right of God) is imposed, most legal schools would suggest the same procedure as for consensual Zina that refers to the confession of the perpetrator or the testimony of four sane adult and male witnesses with all the strict conditions. Any ambiguity would lead to averting the Hadd. As it will be mentioned in following sections, some schools accept knowledge of judges or circumstantial evidence as well.

There are some difficulties in the traditional evidentiary standards if rape is related to Zina. The most notable aspect of pertaining evidentiary standards to Zina and stressing on traditional evidence is the impossibility of the fulfillment of these types of evidence which will be explained below.

\footnotetext{
21 Ibid, at 452 .

${ }^{22}$ Azam Hina, Rape as a Variant of Fornication (Zina) in Islamic Law: An Examination of the Early Legal Reports, The Journal of LAW AND RELIGION FORTHCOMING 1 (SPRING 2013 ).
} 


\section{A. Confession}

The first point about confession is that confession is reliable and admissible only if the confessing person has four characteristics: adulthood, wisdom, intention and authority. Consequently, confession of children or insane people is not acceptable. People should confess with their absolute authority and without any reluctance or threat and should confess seriously and truly. The judge should not assist him or her with confessing nor should he put him or her under pressure. In other words, in principle, any confession which is made by force or torture is not reliable in Islam and does not lead to any punishment. Concerning confession, especially confession to committing Zina, the judge is advised to discourage the defendant from doing so, or to set out certain conditions that will prevent him or her from doing so. In other words, in Islamic law, especially for Zina, the judge should make proving the crime as difficult as he can. ${ }^{23}$ For example, if the judge realizes that the accused cannot speak easily, he should not assist him or her in uttering words, but he should rather make him or her renounce the charge intangibly. If the defendant insists and looks determined to confess explicitly, the judge should find a reason to send him or her home so that he or she regrets his or her confession.

The required number of confessions for Zina is four times before the judges. The accused has to confess and state four times that he commit that crime. The confessions should be done in four different sessions and should be done before judge. If someone confesses fewer than that, sometimes, he or she (the ones who confess) will be sentenced to Tazir punishment (for slander to another part). Another important issue is acceptance of denial, after confession, in crimes such as adultery, rape or incest cases, the sentence of which is stoning or death penalty. In other words, if the accused confess four times, he can deny all of them and the court will accept this denial. Therefore, Hudud punishment will not be executed in the case of refusal after confession. This is, in fact, another special device suggested by Islam in order to keep Zina uncovered, which is the basic policy of the Islamic law. Another major issue is that although Islam has not made the confession to illegal sexual crimes, by counting the denial of such crimesas acceptable - and regarding the confession - as undesirable - confirms the Islamic criminal policy regarding covering (and not proving) these kinds of

\footnotetext{
${ }^{23}$ In fact, this point is custom that has very strong jurisprudential basis in Islamic law. There are many rules and reports regarding this issue in Fiqh and sources of law- making in Islamic law.
} 
crimes, that will be elaborated more in the next section. ${ }^{24}$

Upon analyzing this kind of evidence, it can be said that confession in the past was regarded as the most important evidence for proving a crime. In sexual crimes, however, it is so difficult to prove any of these crimes with confession considering all the requirements imposed in Islamic jurisprudence for it. The main reason is that rape offenders (accused) are not easily willing to confess to the crime four times in the court. Someone who has committed rape and has neglected social, moral, religious and conscientious laws is not expected to confess to his or her crime four times in four separate sessions without any torture or under normal conditions. ${ }^{25}$ On the one hand, the victim is faced with the issue of repeated confessions. Accused has to confess four times. While one confession cannot prove crime, those who rape can refuse to repeat confession in order to be released from heavy punishment. On the other hand, even in cases where those who rape have sufficiently repeated confession, they can reject all of their confessions and then be released from death punishment. Based on what precedes, it is unlikely that a confession actually occurs or assists in proving a crime.

\section{B. Testimony}

Testimony in Islamic law has some requirements that make it inefficient in rape cases. For example, one of the most important conditions for witnesses is that they have to be just and pious people. The most important point is that observing the crime and then being able to testify means committing two religious sins in Islam, that is, inspection and looking at the body of a stranger. First of all, those who commit rape try to choose hidden places because of shame or the fear of being disgraced if their crime is discovered and are not often identifiable except by inspection or violation of privacy. Secondly, the requirement of exact observation of the intercourse for the testimony of this crime does not make the task easy. Seeing the action requires indeed looking at the body of a stranger which is a taboo in Islam and thus leads to committing a sin and a taboo act. Considering that, Islamic laws suggest that one of the requirements of

\footnotetext{
${ }^{24}$ Rahim Nubahar, The Purposes of Punishments in Crimes Required Had, THE QUARTERLY JOURNAL OF MuFID, 2001.

${ }^{25}$ In religious societies, especially in the early age of Islam, in which people accept Hudud punishment in order to get rid of otherworldly punishment, confession has certain significance and is possible. In this context, the purpose of someone who confesses is welcoming punishment and then be totally or partly released from otherworldly punishment. However, this cannot be accepted nowadays, as the intensity of this punishment prevents a (none) believer from confessing.
} 
witnesses is their justice (they have to be pure and away from sins), which means that when any of the above acts is done, it can lead to violation of the justice of observers (witnesses) and his or her testimony is eventually null. ${ }^{26}$

In addition, the number of witnesses in Zina cases should be four males. The major point is that the access to the testimony of witnesses is also not easily possible in rape cases; because with the presence of four just witnesses, a question worth raising is how could rape ever happen in the first place. In addition, the witnesses have to observe not only the sexual relationship, but also exactly the intercourse (in rape, Zina, or adultery etc.). Besides the requirement of watching the intercourse exactly, there are some other conditions. For example, even in cases the witnesses testify that they have seen sexual intercourse between a man and a woman; if they do not know whether their relationship is legal or not, such testimony will not be enough for proving Zina. ${ }^{27}$

Therefore, considering that this crime usually occurs in hidden places and the conditions of exact observation of the intercourse by witnesses are problematic, the efficiency and validity of testimony are practically rejected in rape cases. Other requirements are that the testimony of the witnesses should be clear, without any ambiguity. Witnesses should testify one after another without any time interval. If some witnesses testify and other witnesses do not appear immediately to testify or refuse to testify, the crime (rape or Zina) will not be proven and in this case, the witness will be punished because of unjust accusation. If three witnesses appear to testify rather than four, three witnesses will be punished for unjust accusation as well. Consequently, fear of being exposed to the punishment of unjust accusation also shows practical non-efficiency of testimony to prove rape. Witnesses should also agree whether the female had willed or resisted the sexual act. In sum, based on the discussed requirements for confession and testimony, it is obvious that rape cannot be proven in such judicial systems.

Regarding circumstantial evidence, where there is no direct and positive evidence about penetration, it does not constitute the offence of Zina. Circumstantial evidence may be used as validation but cannot be made the basis of conviction for Zina. ${ }^{28}$ In addition, the difference amongst Islamic schools regarding the evidence for rape is mostly related to validating "knowledge of judges" and "circumstantial evidence", which will

\footnotetext{
${ }^{26}$ Ahmadlu Mahmoud, CRiminal Legal and Judiciary Policy OF IRAN CONCERNED with CRimes BASED ON IlLEGAL SEXUAL Relationship, 156 (Imam Sadegh University 1998).

${ }^{27}$ Ruh Allah Al Musavi Al Khomeini, Tahrir alvasileh p2-408 45 (Ismailieh, Bita 2006).

${ }^{28}$ Muhammad Waqar-Ul-HaQ, Islamic CRiminal LaWs: Hudood Laws \& Rules, With UP-TODATE COMMENTARY 128 (Nadeem Law Book House 1994).
} 
be explained in the following section.

\section{DifFERENT ISLAMIC SCHOOLS AND THE EVIDENTIARY SYSTEM OF RAPE}

As it has been mentioned before, all problems come from this idea that rape falls under Zina and Zina as Hadd crime violates the right of God. However, if Islamic schools interpret the text in another way and consider the dual nature of rape, they will be able to find a solution and thus offer more protection to the victims. Because of the difficulties in providing evidence, some Islamic schools interpret the Islamic text in another way and provide another system to protect victims. For example, an alternative look at rape as a dual crime is common in the Maliki and Shiite Schools of law. These new perspectives resulted in protecting victims more than in other schools. $^{29}$

For instance, from the Maliki perspective, two crimes of Zina, one of them Zina itself and another one referred to as usurpation of sexual organs are identified as rape. This implies that the court imposes two punishments and considers two different procedures followed in order to prove both aspects of the crime. ${ }^{30}$ The Malikis suggest that, in order to prove the occurrence of rape as an act causing physical and emotional breakdowns on the victim, the claimant should provide two male witnesses or one male and two female witnesses. The crime should be treated as a civil claim (because of usurpation of sexual organs), and monetary compensation in the form of dowry against the invader should be imposed. If the claimant fails to provide the necessary evidence, it would result in dropping the charges. However, in Maliki jurisprudence, another significant Fatwa that involves imposing Tazir punishment is noticeable when the Hadd punishment is not established due to lack of evidence, but the judge is enough convinced that the sexual violation has most likely occurred.

On the other hand, Hanafi School of Law would consider rape as a unitary crime which should be discussed under the category of Zina. Accordingly, the same method for proving Zina is adopted besides proving the element of coercion on the female party to drop charges against her. If the occurrence of rape, which is the same as Zina is not proven which is most probable, the Hadd punishment is averted from the male invader and he will be set free without receiving any punishment even in form of Tazir or monetary compensation.

\footnotetext{
${ }^{29}$ However, the practice of Islamic states is something else that sometimes prevents judges to apply these capacities.

${ }^{30}$ Abu'l-Walid Al-Baji, Al-muntaqa Sharh al-muwatta, 7 DAR AL-KITAB AL-ARABI 146 (Beirut).
} 
With regard to the evidentiary system in Shiite schools, it should be mentioned that there is no particular and specific system of evidence for rape, which is seemingly considered as Zina. However, some differences in Shiite schools make an important change for victims at the procedural stages. The first difference and the most significant one relates to who has the burden of proof before the court. From the Shiite perspective, if the victim claims that she has been raped, the judges have to accept it and the other part should prove otherwise. Thus, the burden of proof is not on the victims, but on the accused who should prove that it was a consensual relation. It seems that all Shiite jurists have agreed on that based on the Hadith narrated from Imams. ${ }^{31}$ Another difference is related to validating the knowledge of judges, which is sort of validating circumstantial evidence. This is controversial amongst Muslim jurists (both Shiite and Sunni ones). In the following section, different ideas of jurists on this topic will be discussed.

\section{A. Different Views Concerning the Validity of Knowledge of Judge}

The majority of Shiite jurists and some Sunni jurists agree that judges can apply their knowledge and conviction, using circumstantial evidence, in all claims including civil and criminal cases. When we talk about legality or illegality of knowledge of judge, we do not mean his awareness about other traditional evidences such as confession or testimony; because this kind of knowledge is required for judge to have and it is something necessary for him. What we mean is related to finding and discovering the occurrence of crimes such as rapes or theft because the judge should be sure that these crimes have really been committed. This kind of knowledge is classified into two types: 1. the knowledge acquired by the judge from the outside of the dossiers; for example, he has personally witnessed or has realized a certain accident by associating with the people of society. 2 . the knowledge acquired by him through studying dossier, circumstantial evidence and indications in the dossier. ${ }^{32}$ Therefore knowledge of judges or conviction of judges, as same as circumstantial evidence, refers to anything that manifests the truth. Ibn Qayyim defines it as "al-Bayyinah ismun likulli ma yubayyinu

\footnotetext{
${ }^{31}$ Mohagheghe Ardebili, Majma al faedeh, 13 (Shiaonlinelibrary 1996). Ed Shiekh Mohammd Alrazi Al Hore Al A'meli, Al-vasael al shia, 18 (Shiaonlinelibrary). Al Sheikh Alkoleini, Al kafi, 7 (Shiaonlinelibrary 1988). Al Saed Al Brojerdi, Jame ahadith, 25 (Shiaonlinelibrary 1995). Ibn Edris Heli, Al saraer, 3 (Shiaonlinelibrary 1990). Al Sheikh Al Sadugh, Almoghana, 1, 291 (Shiaonlinelibrary 1995).

${ }^{32}$ Abdualrasul Dayyani, Certitude of the Conscience of Judge Brief Comparison of Legal System of Islam, Iran and France, 51 The Monthly Journal OF CRIMINAL Procedure 25 (1384).
} 
al-haqq" which refers to everything that proves the truth. ${ }^{33}$ Therefore, it is not limited to the testimony of witnesses or confession but actually includes a wider meaning of proof. ${ }^{34}$

Different attitudes regarding the validity of judge's knowledge in proving claims have been offered. The most important attitudes are outlined below:

1. Most Shiite and some Sunni jurists have absolutely accepted the validity of the knowledge of judge. The first written work among Shiite jurists in this regard was produced by Sayyed Morteza. He proved validity of knowledge of judge as presented in his book which is entitled $\mathrm{Al}$ Entesar. ${ }^{35}$

2. Many Sunni jurists and some Shiite have absolutely regarded the knowledge of judge invalid, an idea which is ascribed to Ibn Junaid. ${ }^{36}$

3. Some jurists have exclusively regarded the knowledge of judge authoritative for the cases where rights of people are concerned, but not for the cases of Hudud. The first person to have advanced this theory among Shiite jurists is Ibn Hamzeh. ${ }^{37}$

4. Some accept the validity of knowledge of judge just for the rights of God, but not for the rights of people. ${ }^{38}$

Each jurist gives different reasons for its arguments based mainly on the Quran and Ahadith. Some reasons are also based on intellectual arguments; explaining all of them is outside the scope of this research. However, in short, all of these evaluations and criticisms come to the conclusion that the knowledge of judges is valid in the determination of the violation of the rights of people (such as theft and rape which have dual features) but not with regard to a violation of the rights of God (such as Zina as one of the sexual crimes). So again, these arguments are rooted in the jurists' conceptualization of the term rape that is different.

\footnotetext{
${ }^{33}$ Ibn Qayyim Al-Jawziyyah, Al-turuq al-hukmiyyah fì al-siyāsah al-syar 'iyyah, BEIRUT: DĀR ALKutUB AL-'ILmiYyah, at 19.

${ }^{34}$ Azman Mohd Noor, A Victim's Claim of Being Raped Is Neither a Confession to Zina Nor Committing Qadhf (Making False Accusation of Zina), 8 Muslim World Journal of Human Rights 10 (2011).

${ }^{35}$ Sayyed Morteza Alame Alhuda, Alentesar, (436a.H.) with the Introduction of Sayyed Mohammad Alkhorasan, DAR ALZAVA (Beirut 1985). Mohammadhasan Najafi, Javaher Alkalam fi Sharh Shara Alislam, 41 Dar alkutub alIslamieh 40-88 (Bita 1984). Ruh Allah Al Musavi Al Khomeini, Tahrir Alvasileh, p2-408 (Ismailieh, Bita 2006), ibid, at 2-408.

${ }^{36}$ Mohammadhasan Najafi, Javaher Alkalam fi Sharh Shara Alislam, 41 DAR ALKUTUB ALIsLAMIEH 88-91 (Bita 1984).

${ }^{37}$ Ali Ibn Hamzeh (560A.H.), Alvasileh 218 (Maktab Almarashi, Khayam Publication 1988).

${ }^{38}$ Sheikh Morteza Al Ansari, AlghaZA va ALShahadat 59 (Sheikh Ansari Congress, Qom:

Bagheri 1994). Zein Aldin Jabei Ameli(Second Martyr), Masalek Alafham fi Sharh Shara Alislam, 2, 348 (Basirati 1979).
} 
The jurists who argue against the knowledge of judges emphasize the importance of the principle that says "Hudud (as crimes that violate right of God) are to be treated with leniency and negligence". They say that it is inferred from the Islamic law and jurisprudential viewpoints that the Hudud sentences are all based on negligence, leniency, and prohibition of inspection and acquisition of knowledge. ${ }^{39}$ The main aim for legalizing very strict evidence is to make proving that crime difficult and even impossible. Therefore, if they consider rape as Zina (and Zina is part of Hudud), it means that judges will not apply their own knowledge or any other evidence to prove it, because they simply misunderstand that rape only violates the right of God and should be treated with leniency. In this case, judges are not willing to prove anything or use any kind of evidence and will pronounce acquittal sentence.

On the other hand, another group of jurists believes that rape has dual nature. Because it not only violated right of god, but also right of individual and since it contains private complaints, the judges are obliged to do their best to discover the truth. ${ }^{40}$ Some contemporary Shiite jurists such as Almeh Heli and Mosavi Khomeni believed in the validity of knowledge of judges with regard to this crime. ${ }^{41}$ They believe in the knowledge of judges as evidence because it is the common way all wise people follow, which the holy legislator has also confirmed. In Islamic jurisprudence, it is called Banā Uqalā which means that when all wise people of a time do something and there is no objection from the Prophets or Imams, that action is legal; otherwise the prophet would prevent people from performing it. The wise people trust the probable and uncertain evidence or circumstantial evidence because it is for the benefit of the society. ${ }^{42}$

\footnotetext{
${ }^{39}$ Zein Aldin Jabei Ameli(Second Martyr), Masalek Alafham fi Sharh Shara Alislam, 2,11 (Basirati 1979).

${ }^{40}$ For instance, 'Abd al-Jabbar Ibn Wa'il reported that at the time of the Prophet a woman was raped and she was excused from punishment: When a woman went out for prayer, a man attacked her and raped her. She shouted and he went off, and when a man came by, she said: "That man did such and such to me." And when a company of Ansar came by, she said: "That man did such and such to me." They went and seized the man whom they thought had had intercourse with her and brought him to her. She said: "Yes this is the one." Then they brought him to Allah's messenger. When he was about to pass sentence, the man who had assaulted her stood up and said: "Apostle of Allah, I am the man who forced her against her will." The Prophet said to the woman: "Go away, for Allah has forgiven you." And about the man who had intercourse with her, he said: "Stone him to death. Muhammad Abd al-Rahman ibn Abd al-Rahim al-Mubarakfuri, Tuhfat al-ahwazi bi sharh jami" al-Tirmidzi, 5 Beirut: Dar AL-KutuB AL-ILMiYyah 13 (1990). Abu-Bakr Al-Bayhaqi, Al-sunan alkubra, DAR AL-KUTUB AL-ILMIYYAH 235 (Beyrouth 1994).

${ }^{41}$ Ed Shikh Ebrahim Bahadori Alame Heli, Alame Heli, Tahrir al Ahkam, 5, at 304, 311 (Etemad, Qom 2003).

${ }^{42}$ Ruh Allah Al Musavi Al Khomeini, Tahrir Alvasileh, p2-408 (Ismailieh, Bita 2006). Question 8, characteristics of judge, Jafar Sobhani, Tahzib alusul, 2, The association of instructors 112 (2001). Mohammadhasan Najafi, Javaher Alkalam fi Sharh Shara Alislam, 41 DAR ALKUTUB ALIsLAMIEH 88 (Bita 1984). Sheikh MorteZA Al ANSARI, AlghazA va AlshaHADAT 492 (Sheikh Ansari Congress, Qom:Bagheri 1994). Sayyed Abu Alghasem Al Khoei, Mabani tuklamat almenhaj, 1, at 31 (Lotfi 1987).
} 


\section{B. The Role of Knowledge of Judges in Criminal Procedure}

Although, there is a difference amongst Islamic schools regarding the evidence for rape related to validating "knowledge of judges" and "circumstantial evidence", this section clarifies that practical problems in the criminal procedure and some misunderstanding amongst judges prevent them from applying these forms of evidence in practice. For instance, in some Islamic countries such as Iran that assumes to accept this type of evidence based on Shiite jurisprudence, the judges, in practice, avoid to apply this evidence because of misunderstanding of Islamic policy regarding sexual crimes and combining rules of Zina and rape.

Legality or illegality of knowledge of judges refers to finding and discovering the occurrence of crimes such as rape or theft. It is the responsibility of the judge to ensure that these crimes have really been committed. It can be acquired through different methods and it can include different form of evidences for instance circumstantial evidence, indications in the dossier or expert opinion and so on. ${ }^{43}$

However, with regard to knowledge of judges, in the case of rape, many judges in Iran practically refuse the acquisition of this knowledge because of some reasons such as misunderstanding of the principle of abolishment of the legal punishment (Huddud) in case of uncertainty (Dara principle ${ }^{44}$ ) or severity of rape punishment etc. The point is that the reason why some jurists disagree with exercising knowledge of judge in Hudud such as Zina, is relying on some of the reasons such as the Islamic legal policy of covering crime or "Dara" principle. ${ }^{45}$ The issue of severity of rape punishment causes many judges to be reluctant to issue this sentence. ${ }^{46}$ Before shedding light on this misunderstanding, it is necessary to explain more the policy of covering crime in Islam and the conditions under which it can be done.

Covering crime is regarded as one of the instruments of reducing sexual crimes in Islamic procedural law. It can be defined as a collection of regulations which reduce the possibility of discovering and proving sexual crimes such as Zina as they include rights of God. Covering crime is

\footnotetext{
${ }^{43}$ Dayyani, Abdualrasul Certitude of the Conscience of Judge Brief Comparison of Legal System of Islam, Iran and France, 51 The Monthly Journal OF Procedure 25 (2005).

${ }^{44}$ This principle (تدرا الحدود بالثبهات ) means that if there is even very little uncertainty to prove Zina judges have to avoid to issue Hadd punishment.

${ }^{45}$ Hajar Azari, Protection of Women Victim of Sexual Offences with Especial Focus of THEIR PRIVACY 251 (Tarbiat Modares University 2006).

${ }^{46}$ M. Cherif Bassiouni, Sources of Islamic Law, and the Protection of Human Rights in the Islamic Criminal Justice System, 3 The Islamic Criminal Justice System 23 (1982).
} 
exercised at both stages of discovering and proving it. Considering the definitions of different types of rights in Islamic law and the consequences of this separation ${ }^{47}$, as has already been explained that Zina is included in the crimes related to the violation of the rights of God. ${ }^{48}$ The spirit dominating Islamic rules for Zina and the required evidence, such as testimony of four just male witnesses or four times confession, to prove it, which do not practically occur in most cases, show that the criminal policy of Islam is based on covering sexual crime unless they are committed publically in the society. In fact, these rules have been articulated to protect women against sexual crimes.

Furthermore, regulations resulting from the Dara principle also constitute an obstacle to proving Zina, which is another fundamental base for covering this crime. This principle suggests non-execution of Hudud in doubtful cases. Therefore, in some cases where the defendant confesses fewer than four times or there are fewer than four witnesses, the Hadd punishment is abolished and Tazir is sometimes executed instead. Clearly, these reasons cause the judges not to use the evidence of knowledge of judge in these crimes because of the principle of covering such crimes in investigating the sexual crimes as crimes that violate the right of God. In accordance with the Prophetic directive imposing the Hadd punishment for such crimes, prosecuting those crimes should be avoided as much as possible. Based on this, it can be concluded that establishing and proving Hadd crimes cannot be done through circumstantial evidence or knowledge of judges.

It also represents the fact that even if we accept these two forms of evidence that definitely simplify the proof of rape, there are some problems in the criminal procedure to apply them properly. It is mainly because the traditional schools of law did not think of alternative standards for treatment the case of rape (coercive Zina). This is the reason why, in addition to the principle of covering such crimes, the traditional interpretation of rape as a form of Zina prevents traditional and classic schools of law (mainly Hanafi) from developing more pragmatic evidentiary and procedural doctrines. Jurists ignored the problem that the strictness of the procedure for proving the crime of consensual Zina which can easily end up to averting the Hadd punishment in case of ambiguity would make establishing rape as a coercive form of Zina difficult, which is likely to result in relieving the perpetrators of rape. If the system of evidence requires a victim to offer evidence which

\footnotetext{
${ }^{47}$ Regarding the possibilities of reduction and amnesty in the crimes that violate right of God.

${ }^{48}$ Mohammadhasan Najafi, Javaher Alkalam fi Sharh Shara Alislam 41, DAR ALKUTUB ALISLAMIEH 154 (Bita 1984).
} 
not only is practically impossible but also in case of failing to present it, he/she is accused of committing crime, many victims prefer not to report because they themselves are being victimized in criminal justice systems. In fact, since the evidence required for rape is similar to that of Zina and is not differentiated from it, it becomes hard to prove. Therefore, it can be said that if these crimes are limited to these types of evidence, they cannot be proven in practice.

\section{NEW APPROACH TO EVIDENTIARY SYSTEM}

Rape is considered under the category of Zina, which raises the question of whether it should indeed be a crime violating the right of God and should thus be included in the policy of keeping the crime unrevealed. As was clarified earlier, these differences amongst schools lie in the perception of rape as a violation of the right of God or right of individuals. Some jurists totally exclude adultery and rape from crimes related to the right of people and regard it as a mere crime related to right of God. ${ }^{49}$ Other jurists, however, differentiate between sexual crimes and consider rape as a crime with an aspect related to the right of people. ${ }^{50} \mathrm{It}$ will consequently influence the investigation process. When we consider rape as a crime that violates the right of people, judges are obliged to do whatever they can to protect the right of people, but if we consider it as right of God, the judges have to apply Islamic policy of covering that crime or keeping it undisclosed and try not to prove it. The possibilities to reform these rules by emphasizing the solutions offered by both Maliki and Shiite schools of thought will be evaluated and presented in the sections below.

1. As for the evidence system in Islamic law, some Muslim experts such as Asifa Quraishi have specific viewpoints and suggest that, while the Quran forbids sexual intercourse outside of marriage, it does not suggest any punishment to administer unless Zina happens in public. Based on this view, the Quranic verses, which emphasize the necessity of testifying by four witnesses to prove the occurrence of Zina, were revealed in response to the accusation made against Aisha, the Prophet's wife. In an event, she disappeared for a day from a caravan and then was found and brought to the caravan by a soldier. After this event, some people in Medina accused Aisha of having an illegal sexual relationship. In order to prevent the Muslim from

\footnotetext{
${ }^{49}$ Mohammad Hasan Marashi, New Attitudes in Criminal Laws of Islam, 1 Mizan PubliCATION 237 (1994).

${ }^{50}$ Ruh Allah Al Musavi Al Khomeini, Tahrir Alvasileh,, p2-408, IsMAILIEH 452 (Bita 2006).
} 
accusing honorable women, the Prophet announced the necessity of four witnesses to prove Zina. Reviewing the Quranic verse also indicates that revealing this verse aimed to protect the honor of women against unfair accusation. ${ }^{51}$ It is stated as follows "Those who accuse chaste women, and then are unable to produce four witnesses, flog them with eighty stripes...." 52 The tone of the verse especially the term "chaste women" indicates that God would try to protect the women against the slander and to make it difficult for people to easily make accusations against loyal women. ${ }^{53}$ In another verse about a woman accused by her husband of adultery, we read the following "chastisement shall be averted from her by her calling God four times to witness that he is indeed telling a lie." $" 54$ This verse, like the previous one, emphasizes the fact that a woman's honor should be protected from false accusations. From the second verse, it can be seen that the woman's swear is considered as sufficient for averting the punishment of Zina and proving her innocence. Thus, punishing women because of rumors going around or assumptions has no basis in Islam. In addition, the Quran clearly indicates that Qazf, or slander, is also a major crime which is against the spirit and teaching of Islam. This principle of Islam has unfortunately become a negative point in rape cases and the principle which was meant to support women is now being used against women victims of rape. The necessity of four witnesses in proving rape has resulted in the women's own condemnation.

2. As already pointed out, the Maliki School of Law, among other Islamic legal schools, had a specific look at rape, which led to elaborating the crime of rape as to its definition, evidence and procedure in a different way from Zina. From this perspective, rape is a composite, dual crime consisting of fornication in which God's right is violated and usurpation of property in which an individuals' right is violated. Therefore, considering rape as usurpation or Ightisab, the Maliki jurists made the procedure through which this crime is proven much simpler than Zina. Adopting the same procedure (providing two witnesses) which is used in proving property usurpation crimes helped in this regard. Therefore, they permitted rape victims to support their claims by the testimony of two witnesses (compared

\footnotetext{
${ }^{51}$ Asifa Quraishi, Her Honor: An Islamic Critique of the Rape Laws of Pakistan from a Womansensitive Perspective, WOMEN OF FAITH: MUSLIM WOMEN SCHOLAR-ACTIVITISTS IN NORTH AMERICA (Syracuse University Press 1997).

${ }^{52}$ 24:4.

${ }^{53}$ Atyaf Alwazir, Ymeni Women: The Bearers of Honor, AL-MASAR 7 (Winter 2004).

${ }^{54}$ 24:8.
} 
with the four witnesses needed for Zina) ${ }^{55}$ Finally, this perspective helped the jurists of this school to use circumstantial evidence, or Qara'in in proving the crime of rape, which was not accepted in establishing Zina. This circumstantial evidence includes for instance testimony to having heard her cry, being carried to a place by force, identifying the signs of assault on her body and bleeding. ${ }^{56}$

3. Recognizing knowledge of judges is the method that has been offered by Shiite jurists, mainly the contemporary ones. In fact, it is another method to validate circumstantial evidence. Acceptance of this type of evidence represents the fact that the Shiite school also acknowledges the dual nature of rape that includes both a violation of the right of people and a violation of a right of God. Therefore, in accordance with this approach in Shiite, it can be concluded that knowledge of judges under some conditions is acceptable in crimes such as rape. This type of evidence should also be validated by some valid documents such as inspection of the place, reconstruction of the scene of the crime by the judge, experts' opinions, the ideas of forensic medicine, scientific police, fingerprinting of the documents, blood testing, genetic analysis of the cells, inspection of defendant's body and car and generally all advanced and new devices which can help furnish the crime etc. ${ }^{57}$

Referring to the above-mentioned possibilities which are aimed at simplifying the process of proving crimes at procedural stages and preserving the right of people, it can be concluded that according to some specific perspectives within certain schools of law, rape has both aspects of right of God and of people, which therefore excludes it from the regulation of covering crime; assimilating it to the crimes of violating the right of people. Categorizing rape only under Zina results in violating the rights of the victims. If we accept the dual nature of rape, when a victim of rape complains to the court, the witnesses, police, judge etc. should not try to cover the crime but should use every means to prove it because it also

\footnotetext{
${ }^{55}$ Another important point attended to by Maliki jurists is the relationship between a level of certainty gained by the evidence and the degree of the strictness of the punishment. Accordingly, in cases where both aspects of the crime of rape, i.e. usurpation and coercive fornication are proven, the Hadd punishment for Zina besides the dower compensation will be administered. However, in cases where usurpation is proven (by the testimony of two witnesses) and not Zina, but with a strong possibility that Zina has also occurred, monetary compensation and a lesser punishment known as Tazir will be given. In cases where it becomes clear that the man is innocent and the woman has intentionally tried to accuse him of rape, the woman will receive the punishment of slander.

${ }^{56}$ Ibn Farhun, Tabsirat Al-hukkam fi Usul Al-aqdiya Wa-manahij Al-ahkam, 2 MAKTABAT ALKULLIYY-AT AL-AZHARIYYA 97 (1986).

${ }^{57}$ Davood Karamali, Proving Value of Knowledge and Awareness of the Judge in Sexual Crimes, THE MONTHLY JOURNAL OF PROCEDURE 125 (2001).
} 
contains rights of people. ${ }^{58}$ Therefore, in cases where we face a combination of a violation of the right of God and people, knowledge of the judge or circumstantial evidence is applied for investigating and proving the crime in order not to violate the right of the victims. The judge has to collect different elements of evidence on the basis of which the sentences will be pronounced and if he convinced the crime has happened, he has to administer a proper punishment even from the Tazir category. ${ }^{59}$ In these dual cases, even if the complainant expresses his or her consent and forgives the offender, the investigation about the case would not be stopped because in such crimes that involve dual rights, societal interests were also violated and then judges cannot let the defendant run away from another punishment such as Tazir.

In order to achieve this goal, regulating separate evidence codes is one of the important subjects in judiciary systems and reforming such codes can release the judges from confusion and disorders in using evidence. Lack of comprehensive and independent rules about evidence and the weakness of laws and religious ambiguities concerning some cases such as the nature of such crimes have even prevented judges from applying their knowledge in this regard. Therefore, it is the task of Islamic jurists to remove the above mentioned ambiguities by using accepted religious methods such as interpreting religious and legal sources independently through skillful methods (Ijtihad) etc. and pave the way for the legislators to reform the legal system. Acknowledging the knowledge of judges and circumstantial evidence is sort of Ijtihad meaning that jurists should recognize and highlight the rights of women and other individuals who are violated through rape. In this process, the role of judges is incredibly important; the rules should, however, be reformed too. ${ }^{60}$

\footnotetext{
${ }^{58} \mathrm{Ibid}$. It should be mentioned that this policy should be considered in all investigation process, police, courts etc. All staff of criminal justice system, including judges, police etc. should keep it in their mind that for Zina they do not have to search for evidence to prove it, however, for rape they have to search for every form of possible evidence.

${ }^{59}$ Sayyed Abulfazl Musavian, The TerRitory OF ReAsoning of KNOWledge OF Judge IN JURISPRUDENCE 85 (The Office of Jurisprudence 2006).

${ }^{60}$ It is worth noting that Dara rule does not mean that even Ta'zir punishment is not inflicted for the defendant. So in some cases such as confession, less than 4 the Hudud punishment can be dropped, but Ta'zir sentence can be administered. In other words, the punishment itself is not rejected but the severe punishment of death, which is irreparable, and irreversible is removed. Even sometimes death punishment can be removed after 4 confessions in case of threatening outside the court has been made for confessing. (One of the conditions of confession is confessing before the judge not any other official that has been determined for maintenance of the rights of defendant) and this topic is justifiable in Islamic punishment system that should eventually be done with caution and carefulness in such punishments.
} 


\section{CONCLUSION}

The paper clarified that the fundamental cause behind the opposing positions supported by different Islamic schools of law mainly between the Hanafi and the Maliki (also Shiite and Shafi) regarding this issue is in the definition of rape and the category under which each school places rape. This has major consequences not only for sentencing perpetrators, but also for rules of evidence and procedure. ${ }^{61}$ In other words, different schools have looked at the topic of rape and its related issues from different angles. The Maliki and Shiite schools opine that in case of Zina, only the right of God is violated, while in the case of a rape, the rights of people are violated as well. Therefore, based on Maliki and Shiite Schools, rape involves two kinds of violations, one which is similar to Zina concerns the violation of God's right which is compensated by imposing Hadd punishment and the other one which is violation of the right of the victim which does not occur in Zina. ${ }^{62}$ Thus, they believe that the two kinds of rights are both independent and are not dealt with based on hierarchy. As a result, the satisfaction of divine rights does not prevent the fulfilling of rights of people. On the other hand, based on Hanafi legal system, rape is a variant of Zina in which only God's right is violated and the evidentiary system is as same as Zina. ${ }^{63}$

All discussion and disagreement demonstrate the fact that Zina has come to be used as a punitive measure for women victimized by rape. Despite the fact that the punishments and evidence preserved for Zina were, in principle, meant to protect the honor and dignity of women, nowadays they have unfortunately been interpreted in a way that makes them work against women themselves.

Although different schools such as Maliki and Shiite have attempted to present some solutions and provide different evidentiary systems, at the procedural level, it is up to judges to prove rape or not, based on their perception of the nature of rape and how to categorize it. This special look at rape emphasizes the immorality of the act of rape as an illicit sexual intercourse, but ignores the harms and damages inflicted upon the rape victim and may cause her to be isolated from her society.

\footnotetext{
${ }^{61}$ AZAM HinA, COMPETING APPROACHES TO RAPE IN ISLAMIC LAW (University of Texas at Austin, Forthcoming in Feminism, Law and Religion Ashgate Publishing Ltd. 2013).

${ }^{62}$ Ibid.

${ }^{63}$ Ibid. In this regard Hina Azam says: "These differences can largely be summed up as a tension between a lesser and greater commitment to a proprietary sexual ethics, by which I mean an ethics in which female sexuality is conceived as property, as a usufruct that is commodified and thus monetizable, and for which notions of male ownership, purchase and theft make sense. ....In terms of theocentric versus proprietary concerns, this Hanafi argument clearly prioritizing the former."
} 